\title{
PROFESSOR SIR LUDWIG GUTTMANN, C.B.E., O.ST.J., F.R.S., M.D., F.R.C.P., F.R.C.S., D.Sc.(Hon), LL.D.(Hon), D.Ch.(Hon)
}

I923
I924
I924-I929

I928-I929
I930
I933-March
I939
I937
March I939

I940-I943

Ist Feb. I944

until November I976

I947

I948

Since 1952

\section{Academic Career}

Qualified as doctor at Freiburg, Germany.

M.D. Freiburg.

Assistant and later First Assistant at the Neurological and Neurosurgical Department of Professor O. Foerster, Breslau, and the Department of Psychiatry, Hamburg University.

Neurosurgeon at the Department of Psychiatry, Hamburg.

Reader in Neurology, University Breslau (Dozent).

Director of the Department of Neurology and Neurosurgery, Jewish Hospital, Breslau.

Medical Director of the whole hospital.

Emigrated to England, with a Grant from the Society for the Protection of Science and Learning, to become a Research Fellow at the Nuffield Department of Neurosurgery, Oxford University. Member of the Senior Common Room, Balliol College, Oxford.

Member of the Peripheral Nerve Injury Unit, Wingfield Morris Orthopaedic Hospital, Oxford. Experimental animal research on nerve regeneration, galvanic exercise, nerve suture material, inhibition of neuroma formation.

At request of British Government, opened a new Spinal Unit at Stoke Mandeville Hospital, Aylesbury, as one of the preparations for the Second Front.

Held the following appointments:

Director of the National Spinal Injuries Centre, Stoke Mandeville Hospital until I966.

Consultant to Chaseley Home for Paraplegic Ex-servicemen, Eastbourne.

Consultant to Duchess of Gloucester House, London

(Ministry of Labour Hostel for paraplegics).

Consultant to Spinal Unit, Star \& Garter Home for Ex-servicemen, Richmond.

Neurological Consultant to Oxford Regional Hospital Board.

Consultant in charge of Spinal Unit, Rookwood Hospital, Cardiff, I952-I966.

Honorary Consultant to Lyme Green Settlement for Paraplegic Exservicemen, Macclesfield.

Since I966 Emeritus Consultant to the National Spinal Injuries Centre, Stoke Mandeville.

Member of the Royal College of Physicians (M.R.C.P.) being exempted from examination on account of previous work.

Founder of the Annual Stoke Mandeville Games for the Paralysed, which in 1952 became the first international sports ever for the paralysed.

In 1956, during the Olympic Games in Melbourne, the International Olympic Committee awarded the Fearnley Cup to the Organisation of the Stoke Mandeville Games for outstanding achievement in the service of the Olympic Idea. The first time that this Olympic Award came to Great Britain and the first time since the foundation of the Olympic Games that an Olympic Award has been given to a Sports Organisation for severely disabled.

Consultant in Rehabilitation to the World Veterans Federation. Founder Chairman of the World Committee on Paraplegia of the International Society for the Welfare of Cripples from I953-I960. 
1957

Professor Ordinarius (Germany), dated back to I 942 on account of the Restitution Law in Germany.

Advising building Spinal Injuries Centre, Basle, Switzerland.

I959 President of the International Stoke Mandeville Games Committee.

President of the Greater London Association for the Disabled.

I960 Founder-President of the British Sports Association for the Disabled, (B.S.A.D.) which hold annual Multi-Disabled Sports Festivals for children (June) and Adults (September).

I96r Fellow of the Royal College of Surgeons (London) F.R.C.S.

Honorary Degree of Doctor of Surgery of Durham University.

I96I-1970 Founder-President of the International Medical Society of Paraplegia.

Editor-in-Chief of the International Medical Journal Paraplegia.

1962 Vice-President of the British Chartered Society of Physiotherapy. Fellow of the Royal College of Physicians (London) F.R.C.P.

1964

Professor Ordinarius Emeritus, Cologne University, Germany. Vice President of the International Sports Organisation for the Disabled (I.S.O.D.)

I966

1967

1968

1969

President International Sports Organisation for the Disabled (I.S.O.D.). (Re-elected in 1968 by acclamation) and 1977 .

Opening Spinal Injuries Centre, Basle, Switzerland.

Address: 76th Annual Meeting of the American Association of Neurological Surgeons (Cushing Society).

Director of the newly built Stoke Mandeville Sports Stadium for the Paralysed and other Disabled: first of its kind in the world (opened on 2 August 1969 by Her Majesty The Queen).

Chairman of the Executive Committee: British Paraplegic Sports Society.

Since 1948 has paid official visits to other countries to lecture and advise in the treatment and rehabilitation of paraplegia and other types of disablement, at the request of Universities, Governments and Institutions, including the following: Argentine, Australia, Belgium, Brazil, Canada, Colombia, Czechoslovakia, Egypt, Ethiopia, Finland, France, Germany, Greece, Holland, Hong Kong, Hungary, India, Ireland, Israel, Italy, Jamaica, Japan, Luxembourg, Malta, New Zealand, Norway, Pakistan, Poland, Rumania, Russia, South Africa, Spain, Sweden, Switzerland, Uganda, Uruguay, U.S.A., Zambia.

\section{Government Awards}

I950 Officer of the Order of the British Empire (O.B.E.).

1952 Commander of the French Order 'Oeuvre Humanitaire'.

I958 Gold Medal of Merit (Dutch Ex-servicemen's Association).

Officer of the Order of St John of Jerusalem.

1960 Commander of the Order of the British Empire (C.B.E.).

I96I Commendatore nell'Ordine 'Al Merito della Republica Italiana'.

1962 Officer of the Order of Orange-Nassau (Holland).

Great Cross of the Order of Merit of the German Federal Republic.

1963 Commander Cross of the Order of King Leopold II (Belgium).

Silver Medal, Red Cross Soc., Spain.

I964 Croix d'Officer du Merite Combattant (France).

Order of Merit of the Rising Sun (Japan).

I966 Knighthood.

I97I Order of Merit of the State of Bavaria (Germany).

I972 Gold Star of the Grand Cross of Merit of the Federal German Republic. Presented to him by the President, Dr Gustav Heinemann.

The Olympic Gold Medal of Labour presented to him by the King and Queen of the Belgians.

1974 Finnish Sports Medal with the Golden Cross.

I975 La medaille d'or de la Jeunesse et des Sports (France).

\section{Other Honours and Distinctions}

I950 Honorary Member of Neurological and Neurosurgical Society Montevideo, Uruguay, Honorary Member of Orthopaedic Society, Cordoba, Argentina. 
1952 Ist Albee Memorial Lecturer (Kessler Institute for Rehabilitation, U.S.A.).

I953 First Recipient of Rehabilitation Prize presented by World Veterans Federation.

I954 Member of the Athenaeum Club, London (Rule III).

1956 Fellow of the Royal Society of Arts (F.R.S.A.).

I957 Honorary Member of the British Council for Rehabiliatation.

Patron of the Jewish Association for the Welfare of the Disabled.

I958 Corresponding Member of the Society of German Neurologists and Neurosurgeons.

I960 International Prize of Association de Invalidos e Impedidos, Seville, Spain.

Honorary Gold Needle of the German ex-Servicemen's Association V.D.K.

Honorary Gold Needle of the D.V.S. Germany (German Disabled Sports Society).

I96I Elected Honorary Citizen of the Borough of Aylesbury (Freeman).

President of Greater London Association for the Disabled.

Dr Ruhemann Bronze Plaque for the most outstanding work in the field of Sport

Medicine (2oth Congress of German Medical Association of Sport Medicine).

Patron of the Irish Paraplegic Association.

I962 Street named: Dr Guttmann Laan at Doorn, Holland.

I963 Corresponding Member of German Association of Accident Medicine.

Vice-Patron, British Polio Fellowship.

I964 Reichsbund-Verdienstmedaille, Germany: Hamburg.

First Spinal Paraplegic Unit in Spain (Barcelona) called 'Instituto Guttmann'.

I965 Visiting Professor at Columbia University, New York.

1966 Opening of the First Spinal Injuries Centre in a German University (Heidelberg) named: Ludwig Guttmann Haus.

Hostel for Tetraplegics and severely disabled Paraplegics at Stoke Mandeville Hospital, named Sir Ludwig Guttmann Hostel.

Patron of the Rhodesian Paraplegic Association.

President, National Association of Swimming Clubs for the Handicapped.

1967 President, English Paraplegic Sports Association.

Patron, New Zealand Paraplegic and Disabled Sports Federation.

Corresponding Member of Neurological Association, Switzerland.

I968 Hon. Member, American National Paraplegia Foundation.

I969 Hon. Doctor of Law (LL.D.) Dublin University.

Opening of Stoke Mandeville Sports Stadium for the Paralysed and other Disabled by

Her Majesty The Queen on the occasion of the 1969 International Stoke Mandeville Games for the Paralysed.

Dec. 1969 Visiting Professor at Duke University, North Carolina, U.S.A.

I970 Illuminated Citation from the Massachusetts Department of Public Health during a visit to Boston at the Invitation of the American National Paraplegia Foundation.

Lectured at the invitation of the American National Paraplegia Foundation at Boston, Washington, Houston, Los Angeles, Long Beach, Phoenix, Chicago.

Invited by the Spanish Government to advise in the setting up of a 200 bed National Spinal Injuries Hospital in Toledo.

197I Hon. Member, La Francaise Société de Neurologie.

Honorary Doctor of Science, (D.Sc.) Liverpool University.

Hon. Member der Deutschen Gesellschaft für Neurologie.

Corresponding Member of Gesellschaft für Wirbelsäulenforschung in Germany (Society for research on the spine).

Opened new Spinal Injuries Unit at Phillipshill Hospital near Glasgow.

Delivered Patrick Haglund Memorial Lecture, Stockholm.

Visit to New Zealand to advise on the setting up of Spinal Units. The Government has now given money for two Spinal Units (Auckland and Christchurch).

Visit to Israel to advise Government in setting up a Spinal Injuries Centre at Tel Hashomer Hospital.

1972 Laid the Foundation Stone of the Sir Ludwig Guttmann Military Spinal Injury Centre, Tel-Hashomer, Israel.

Lecture Visit to Colombia. Member of the Colombian Physical Therapy Association.

I973 Visit to Malaysia to advise the Malaysian Government on the setting up of a National Spinal Injuries Centre.

Street Naming Ceremony of Ludwig-Guttmann-Strasse in Heidelberg.

Appointed Honorary Lieutenant Colonel Aide-de-Camp in the Alabama State Militia on Governor Wallace's Personal Military Staff. 
I974 Honorary Member of Hungarian Traumatology Society.

Elected as Individual Member of the Central Council of Physical Recreation.

Consultant to Unesco International Congress on Sport and Physical Education, Moscow.

1975 Corresponding Member of the Polish Medical Society.

Gold Medal of Sport from the City of Lyons, France.

Sportsfield at Santa Lucia Rehabilitation Centre, Italy, named Sir Ludwig Guttmann Sportsfield.

I976 Honorary Fellowship of the Royal Canadian College of Physicians and Surgeons. Fellow of the Royal Society, London.

Invitation for lecturer at Congress of Neurosurgeons, Gramado, Brazil.

Golden Key presented by the American Congress of Physical Medicine, San Diego, U.S.A.

Honorary Doctorate of Medicine and Surgery, Basle University, Switzerland; one of the oldest universities on the continent.

President of The Bath Institute of Medical Engineering.

1977 Life member of the Parapletic and Quadriplegic Association of Australia; opening ceremony of Quadriplegic Hostel, Perth, Australia.

Opening of New Wing at Department of Physical Medicine, University Geneva, Switzerland.

Awarded the Rehabilitation Prize of 1977 by the Reichsbund, Germany.

Annual Lecture at the Rudolph Virchow Medical Society, New York, received the Virchow Medal and Scroll.

\section{List of Publications from 1928 to 1938 in Germany}

I Serobiologische Untersuchungen bei Epileptikern (gem. m. Altenburger) Zeitschr:f. d. ges. Neurol. E Psych., I12, I928.

2 Pathophysiologische, pathohitologische und chirurgisch-therapeutische Erfahrungen bei Epileptikern. Zeitschr. f. d. ges. Neur. E Psych., 136, I930.

3 Zur Frage der Nachbestrahlung operierter Hirntumoren, Strahlentherapie, 59, 1937.

4 Möglichkeiten und Grenzen der Encephalographie bei cerebraler Kinderlähmung, Fortschr. a. d. Geb. d. Röentgenstrahlen, 40, 1929.

5 Die Bedeutung der Encephalographie für die Diagnose und Therapie der cerebralen Kinderlähmung. Med. Kli., I930.

6 Über einen Fall von Entwicklungsstörung des Gross-und Eleinhirns mit Balkonmangel. Psych.-neurol. Wochenschr., 1929, 37.

7 u. 8 Diagnostische Irrtümer infolge technischer Mängel bei Encephalographie, Psych.neurol. Wochenschr., 37 und 45, I 929.

9 Das encephalographische Bild der progressiven Paralyse und seine klinische Bedeutung (gem. m. Kirachbaum). Zeitschr. f. d. ges. Neurol. Psych., I21, I929.

Io Über Möglichkeiten und Grenzen der Encephalographie für die Art-u. Lokaldiagnose von Hirngschwülsten. Refereat auf Einladung des Vorstandes d. Deutschen Gesellschaft für Inner Medizin u. Neurologie i. d. Tschechoslowakei, Prag, Mai 1936.

I I Über Möglichkeiten und Grenzen der Angiographie (Moniz) und Ventrikulographie (Dandy) bei der Diagnose von Hirntumoren. 'Lisboa Medica', 12, 1937.

I2 Encephalographie bei den Tumoren der Grosshirnheimsphaere und den Tumoren der hinteren Schädelgrube. Refereat auf Einladung des Vorstandes d. 1. Internationalen Neurologenkongresses in Bern, I93 I, ref. Neurol. Zentralblatt, 6I.

I3 Roentgendiagnostik des Gehirns und Rückenmarks durch Kontrast-verfahren (Handbuch d. Neurologie v. Rumcke und Foerster, VII. 2. 1937) (Monograph 300 pages).

I4 Über Pneumacephalia intracranialis traumatica. Zeitschr. f. d. ges. Neur. E Psych., I28, 1930 .

I5 Zur Therapie der Pneumacephalia intracranialis traumatica. Zeitschr.f.d.ges. Neur. E Psych., 140, I 932.

I6 Störungen der Liquorzirkulation und-Resportion bei Psychosen. Dt. Zeitschr. f. Nervenheilkunde, III, I929.

I7 Über Störungen der Liquorresorption bei Psychosen. Arch. f. Psych., 88, I 929.

I8 Physiologie und Pathologie der Liquormechanik und Liquordynamik, Handb. $d$. Neurol. VII, 2, 1937. (Monograph I Io pages.)

I9 Trauma und Nervonsystem. Zeitschr. d. Bahnärzte, Nr.9, I93 I.

20 Trauma und Wirbelsäule, Refereat auf Einladung d. Vorstandes, d. Deutschen Gessellschaft $\mathrm{f}$. Unfallheilkunde und Versorgungsmedizin. Hefte f. Unfallheilkunde, 8, I93I. 
2I Cerebrale Komplikationen bei Thrombangiitis obliterans (gemeinsam m. O. Foerster). Arch. f. Psychiatrie, Bd. Io0, I933.

22 Klinische und anatomische Beobachtungen bei Thrombangiitis obliterans mit cerebralen Störungen (wissenschaftl. Festschrift f. Dr. Reinhold, Verlag Rohrer), Brünn, I936.

23 Die Wirksamkeit der Magengewebsdiät auf die funikuläre Spinalerkrankung und auf die psychischen Störungen der Anämia perniciosa. Zeitschrift f. d. ges. Neur. E Psych., Bd. I37, I93I.

24 Nucleare Lähmungen bei anämischer funikulärerSpinalerkrankung und ihre Behandlung, (gemeinsam mit O. Foerster). Zeitschr. f. d. ges. Neur. E Psych., 147, 1933.

25 Über ein im Abortivum 'Apiol' enthaltenes Nervengift, Med. K1. I6, I932.

26 Zur Frage der Multiplen Sklerose, Vortrag gemeinsam m. Gagel a. d. Jahres versammlung d. Südostd. Psych. und Neur. Arch. f. Psych., 99, I932.

27 Chronaxie und Aktionsstrombild bei Ermüdung durch Willkürkontraktion (gemeinsam m. Altenburger). Zeitschr. f. d. ges. Neur. E Psych., Bd. II 5, 1928.

28 Zur Topik und Pathophysiologie der Schweisssekretion (gemeinsam m. List) Zeitschr. f. d. ges. Neur. E Psych., Bd. I 16, I 929.

29 Die nervösen Leitungsbahnen der Schweisssekretion beim Menschen. Deutsche Zeitschr. f. Nervenheilk., Bd. I07, 1928.

30 Die Schweisssekretion des Menschen in ihren Beziehungen zum Nervensystem (Habilitationsschirft) Zeitschr.f. d. ges. Neur. \& Psych., Bd. 135, I93 I.

3I Motorische und vegetative Grenzzonenreflexe bei Läsionen peripherer und zentraler Abschnitte des Nervensystems. Zeitschr.f. d. ges. Neur. E Psych., Bd. I47, 1933.

32 Epidemiologische, klinische und histopathologische Erfahrungen während der Poliomyelitisepidemie 1932 in Schlesien Med. K1. 28, 1933.

33 Ein neues und einfaches kolorimetrisches Verfahren zur Untersuchung der Schweissdrüsenfunktion. Klinische Wochenschrift, Nr. 35, I 937.

34 Zur Frage der Wiederherstellung der Schweissdrüsenfunktion in Hauttransplantaten. Dermatol. Wochenschrift, Bd. 77 Heft 2, 1938.

35 Lähmung des Nervus thoracicus longus mit Sympathicus-Schädigung als Sportverletzung (Gleichzeitig ein Beitrag zur Pathophysiologie der Schweisssekretion). Dt. Zeitschr.f. Nervenheilk., Bd. I45, I938, Heft I-4.

36 Die reflektorischen Beziehungen zwischen Viscera und Schweissdrüsen in ihrer Bedeutung bei Erkrankangen innerer Organe (der Viscero-Sudorale Reflex) 'Confinia Neurologica' Heft 4, 1938 im Druck.

\section{Vorträge und Fortbildungskurse}

Psychiatrische-neurologischer Fortbildungskursus für Ärzte in Hamburg 1929. dreistündige Vorlesung über Encephalographie und die chirurgische Behandlung der Epilepsie sowie anderer Gehirnerkrankungen.

Vorträge bezw. Demonstrationen an den Sitzungen der Südostdeutschen Neurologen und Psychiater in Breslau über die verschiedensten Themen aus der Neurologie und Neurochirurgie 1929-1932, referiert in d. Kli. Wochenschr. und Med. Klinik.

\section{List of Publications and Reviews since 1939 by Sir Ludwig Guttmann, C.B.E., F.R.S., Hon.D.Chir., M.D., F.R.C.P., F.R.C.S., Stoke Mandeville Sports Stadium for the Paralysed and other Disabled, Harvey Road, Aylesbury, Bucks}

1940

I Study on sweat disturbances in peripheral nerve lesions. F. Neurol. and Psych. 3, 197.

2 Disturbance of sweat secretion after extirpation of certain cervical sympathetic ganglia. F. Anat. (London) 74, 538 .

I94I

3 A demonstration of the study of sweat secretion by the quinizarin method. Prod. Roy. Soc. Med. 35, 77.

4 The local extension of nerve fibres into denervated areas of skin. F. Anat. 4, 206, in co-operation with G. Weddell and E. Guttmann.

5 Review on rehabilitation after lesions of the nervous system. Medical Research Council. 
6 Rehabilitation after injuries to the central nervous system. Proc. Roy. Soc. Med. 35, 305.

7 The rate of regeneration of nerves. F. Exper. Biol. 19, I4, in co-operation with Young, Medawar and E. Guttman.

8 The effect of electrotherapy on denervated muscles in rabbits. Lancet, Feb., I69, in co-operation with E. Guttman.

9 The chemical inhibition of nerve regeneration and neuroma formation in peripheral nerves. F. Neurol. and Psych. 5, I3 I, in co-operation with P. Medawar.

Io Review on the surgical aspect of spinal cord and cauda equina injuries. Medical Research Council.

I 943

I I

Experimental study on nerve suture with various suture materials. Brit. F. Surg. 30, I2O.

The effect of galvanic exercise on denervated and re-innervated muscles in the rabbit. F. Neurol. Neurosurg. 7, 7, in Psych. in co-operation with E. Guttman.

I3 The early treatment of traumatic paraplegia. Middlesex Hospital fournal, 44, 67, in co-operation with P. H. Sandifer.

I4 New hope for spinal cord sufferers. New York Medical Times, 73, 318. Written at the request of the Ministries of Health and Information.

I5 Acridine-sulphonamide compounds as wound antiseptics: clinical trials of flavazole. Lancet, July, p. 97, in co-operation with J. McIntosh, R. H. M. Robinson, F. R. Selbie, J. P. Reidy, and H. Elliott Blake.

Rehabilitation of spinal cord invalids. Report of lectures and speeches given at Rehabilitation Short Course, Oxford, p. 27.

I Nursing problems in the rehabilitation of spinal cord injuries. Nursing Times, 42, 798. Written at the request of the editor of Nursing Times.

I 8 Rehabilitation after injury to the spinal cord and cauda equina. Brit. F. of Physical Medicine, 9,130 and 162.

I9 Problems of Physiotherapy in traumatic paraplegics. American Arch. of Physical Medicine. Written at the request of the Committee of the British Association of Physical Medicine.

Inspiratory vasoconstriction after spinal injuries. F. Physiol. 107, 67, with R. W. Gilliatt and D. Whitteridge.

Treatment and prognosis of traumatic paraplegia. Proc. Roy. Soc. Med. 40, 219.

Management of the quinizarin sweat test. Post-graduate Medical f. 23, 353.

23 Effects of bladder distension on automatic mechanisms after spinal cord injuries. Brain 70, 36I, (with D. Whitteridge.).

24 Disturbances of automatic mechanisms after spinal cord injuries in man. 17th Internat. Physiol. Congress Abstr. Com. 232.

1948

Bedsores. Brit. Surg. Practice 2, 65 (Publishers: Butterworth, London).

26 Care and rehabilitation of paraplegic patients in England: 'The Caliper'. F. Canad. Parapl. Assoc. III, I, 22.

27 Readjustment to a new life (I-Psychological aspects). 'The Cord', I, I, 52.

28 Readjustment to a new life (I I-Physical aspects). 'The Cord', II, I, 55.

29 Management of paralysis. Brit. Surg. Pract. 6, 445 (Publishers: Butterworth, London).

30 Surgical aspects in traumatic paraplegia. F. Bone and foint Surg. 31B, 389.

3 I Principles of physiotherapy in the treatment of spinal paraplegia. Physiotherapy, 35, I 57.

32 The effect of prostigmine on the reproductive function in the spinal man. IV Intern. Neurol. Congress Paris. Com. Vol. II, 69. 
Effects of pitiotrin in hydronephrosis in paraplegics. Proc. Roy. Soc. Med. 42, 546. Readjustment to a new life (II-Physical aspects). 'The Cord', II, 2, 2 I.

Readjustment to a new life (III-Resettlement aspects). 'The Cord', II, 4, I8.

1950

36 Rehabilitation after injuries to the spinal cord and cauda equina. W. Guthrie-Smith (ed.) Rehabilitation, 2nd edition (Publisher: Baillière, Tindall and Cox, London).

37 Muscle movements. Brit. Assoc. for Advancement of Science, Section Physiology, 3oth September.

I95I

Problems of physiotherapy in poliomyelitis. Editorial in Brit. F. Physical Med. 14, 73. The care of the paraplegic patient. Festival Programme of R.S.M. and B.M.A., Section: Neurosurgery.

Principles of rehabilitation in disseminated sclerosis. Brit. fourn. Phys. Med. 189, Vol. I5, No. 8).

4I 'Olympic Games' for the Disabled, World Sports, October.

42 On the way to an international sports movement for the paralysed. 'The Cord', Vol. 5, No. 3 .

43 Paper in French-'Paraplegics'-Centre International de l'enfance travaux et documents $\mathrm{V}$, page 235 .

44 Studies on reflex activity of the isolated cord in the spinal man. F. Nervous and Mental Dis. II6, 957.

45 Cardiovascular responses to bladder distension in paraplegic patients. F. Physiol. 12I, 58I, in co-operation with Whitteridge, Cunningham and Wyndham.

46 Principles of reconditioning severely injured men, with particular reference to the management of paraplegia. Symposium on Stress, Walter Reed Army Medical Center, Washington, D.C.

47 The treatment and rehabilitation of patients with injuries of the spinal cord. Monograph in Vol. Surgery, Medical History of the Second Word War, pages 422-516 (Publisher: H.M. Stationery Office, London).

48 Viscoral activity and peripheral circulation in the spinal man. Ciba Foundation Symposium on Peripheral Circulation in Man, pages 192-203 (Publisher: T. and A. Churchill, London).

49 De paralyserades olympaid. Varlshorisont, Goteborg, February, Vol. 2, 3-6.

1954

50 Looking back on a decade. 'The Cord', Vol. 6, No. 4, 9-23.

$51 \& 52$ Statistical survey on one thousand paraplegics and initial treatment of traumatic paraplegia. Proceedings of R.S.M. Dec. 1954, Vol. 47, No. I2 (Section of Orthopaedics with Section of Neurology).

53 The problem of treatment of pressure sores in spinal paraplegics. Brit. F. Plastic Surgery, Vol. VII, No. 3.

54 The management of the paraplegic patient. The Practitioner 176, 157-170.

55 'Victory over paraplegia'. Contribution to Sir Ian Fraser's Book, Conquest of Disability', pages 59-79.

56 The absorption of ethyl alcohol in complete lesions of the spinal cord following intrathecal injection. Excerpta Medica: Neurol. and Psych., Section 8, Vol. 8, No. 9, 862, in co-operation with R. Robinson.

57 Grundsatzliches zur Rehabilitation von Querschnittsgelahmten. Deutsche Zeitschrift f. Nervenheilkunde, Bd. I75, S. I73-190.

58 Rehabilitation and sports. The Word Veteran, Jan.

59 Die Rehabilitation von Querschnittsgelahmten des Ruckenmarks. Deutches Medizinisches fournal, 326-330).

60 Management and rehabilitation of spinal cord injuries. Bulletin of Post-grad. Committee in Med., Univ. of Sydney, Australia, Vol. B, 25-58. 
6I Vasometer responses in the foot to raising body temperature in the paraplegic patient. F. Physiol. 136, 547-555, in co-operation with K. E. Cooper and Helen M. Ferres.

62 Problem of pain and paraesthesia in spinal paraplegia. Proc. 7th World Congress I.S.W.C., London, 443-449.

63 The significance of sport in the rehabilitation of the disabled. Proc. 7th World Congress I.S.W.C., London, 295-299.

64 The problems of spina bifida cystica. Proc. R.S.M., Vol. 50, No. 10, 742-745 (Section of Paediatrics, 28-3I).

65 Traumatic spinal paraplegia: principles of modern treatment and rehabilitation. Recenti Progressi in Medicina, Italy.

1958

66 Thermoregulation in spinal man. F. Physiol. 142, 406-419, in co-operation with F. Silver and C. H. Wyndham.

67 Die Bedentung des Sportes in der Rehabilitation von Querschnittsgeelahmten des Rückenmarks. Intern. Congress on Rehabilitation etc., Leipzig, Germany, pp. I6II65. (Publisher: S. Thieme, Leipzig).

68 Physiotherapy in Spinal Paraplegia. In Suspension Therapy by M. Hollis and M. H. S. Roper, I 47-I69 (in co-operation with Miss D. T. Bell, Publishers: Tindal and Cox, London).

69 The regulation of rectal function in spinal paraplegia. Symposium on Rectal Continence. Proc. Roy. Soc. Med. 52, 86-89.

70 The place of our spinal paraplegic fellowmen in society (Dame Georgina Buller Memorial Lecture). A survey on 2,000 patients. Rehabilitation, 30, I5-27.

7I Management of spinal cord injuries. In Modern Trends in Diseases of the Vertebral Column, R. Nessim and H. Jackson Burrows, 245-262 (Publisher: Butterworth, London).

1960

72 Rehabilitation. Intern. Review of the Army, Navy and Air Forces Medical Services 33, 60-65 (Ist. Intern. Advanced Course for Tutor Med. Officers).

The management of the spinal paraplegic child. Mother and Child, August, 3-7.

I96I

73 The management of paraplegia. Med. Manual, pp. I9-3I (Publisher: Wright, Bristol).

74 Nursing in Spinal Paraplegia, pp. 255-280. (Textbook on Orthopaedic Nursing) (Publisher: Faber and Faber).

75 The sexual problem in spinal paraplegia. Proceed. Scientif. Meeting, Intern. Stoke Mand. Games, Rome 63-69.

76 Fehler und Gefahren beider Frübehandlung der traumatischen Querschnittslahmung. Langenbecks Archiv. and Deutsche Zeitschr. f. Girurg. 298, 194.

77 Our paralysed fellowmen at work. Rehabilitation 43, 9-I7.

78 Sport and the disabled. In Sports Medicine, pp. 367-391, (Publisher: Arnold, London).

79 The National Spinal Injuries Centre, Stoke Mandeville Hospital. Monthly Bull. of Min. of Health and Publ. Health Labor. Service, 21, 60-7I.

80 The first ten years of the International Stoke Mandeville Games for the Paralysed. 'The Cord', I4, No. 4, 30-39.

8I Rehabilitation of Traumatic Spinal Paraplegics at the National Spinal Injuries Centre, Stoke Mandeville. Proceed 3rd. Intern. Congress zur Forderung der Arbeit und der Arbeitnehmer, Luxembourg, May 1962.

82 The road to recovery. Opening address at the Annual Congress of the Chart. Society of Physiotherapy, 263.

83 Effect of tilting on the cardiovascular responses and plasma catecholamine levels in spinal man. Int. F. Paraplegia I, 4, in co-operation with Munro, Robinson and Walsh.

84 The motility of the pelvic colon following complete lesions of the spinal cord. Int. f. Paraplegia I, 93, in co-operation with $M$. Connell and H. Frankel. 
Observations on the aetology of vesigo-ureteric reflux. Int. F. Paraplegia I, I84. The paraplegic patient in pregnancy and labour. Proc. Roy. Soc. Med. 56, 383.

The rehabilitation of the traumatic spinal paraplegic by work and sport. Proceed 14 Intern. Congress of Occupational Health, Madrid Excerpta Medica Foundation, I-I 5 .

20 Jahre Rehabilitationsarbeit an Querschnittsgelahmten. Munchener Medizinische Wochenschrift, January.

89 The married life of paraplegics and tetraplegics. Int. F. Paraplegia, 2, No. 3, October.

The International Stoke Mandeville Games for the paralysed: Tokyo 1964. Physiotherapy, March.

Reflections on sports for the physically handicapped. Physiotherapy, August.

Coming-of-age of the National Spinal Injuries Centre. 'The Cord', Vol. I7, No. I, pages 8-I3.

Services for the treatment and rehabilitation of spinal paraplegics and tetraplegics in

Great Britain. Trends in Social Welfare, pp. 319-336 (Publisher: Pergamon Press). Electromyographic studies on reflex activity of the intercostal and abdominal muscles in cervical cord lesions. Int. F. Paraplegia 3, No. I, in co-operation with J. R. Silver. Cardiac irregularities during labour in paraplegic women Int. F. Paraplegia, 3, No. 2, in co-operation with H. L. Frankel and V. Paeslack.

96 A new turning-tilting bed. Paraplegia, 3, I93.

97 Demonstration of a special electric control for a power-driven wheelchair for high spinal cord lesions. Paraplegia 3, 197, in co-operation with R. G. Maling.

A study of the space requirement of wheelchair users. Paraplegia 4, 24, in cooperation with W. F. Floyd, C. Wycliffe Nobel, Miss R. K. Parkes and Mrs J. Ward. Comparative studies on endogenous creatinine and urea clearance in paraplegics and tetraplegics. Paraplegia, 3, 230, in co-operation with J. R. Doggart and J. R. Silver.

Io० The value of intermittent catheterisation in the early management of traumatic paraplegia and tetraplegia. Paraplegia, 4, 63.

IOI Die Pathophysiologie und Behandlung der Neurogenen Blase. Verhandlungbericht der Deutschen Gesellschaft für Urologie, page 98 (Publisher: Springer, Berlin).

102 Traumatic paraplegia and tetraplegia in ankylosing spondylitis. Paraplegia, 3, I 88.

Cholesterol and protein studies in early stages of traumatic paraplegia and tetraplegia. Paraplegia, 5, 49, in co-operation with K. B. Edwards and H. Frankel.

I04 The Stoke Mandeville Games (Abbottempo 3, 2, published by Abbott Universal Ltd.).

I05 Water therapy and water sport for the physically handicapped with special reference to the paralysed. The Institute of Baths Management, Proceedings of 37th Annual Conference, Blackpool, pages I28-I40.

I06 New turning-tilting bed and head traction unit. British Medical fournal, 288-289.

I07 The initial treatment of traumatic paraplegia and tetraplegia. Contribution to Sir Harry Platt's 8oth Birthday Jubilee Book published by the Polio Research Fund, London.

I08 The history of the National Spinal Injuries Centre, Stoke Mandeville Hospital. Paraplegia, 5, No. 3.

I09 Symptomatology of spinal cord lesions. Volume II, Handbook of Clinical Neurology, Ed. P. J. Vinken and G. W. Bruyn (Publisher: North-Holland Publishing Company).

I IO Die Initiale Behandlung von Rückenmarksverletzungen nach Wirbelbrüchen. Annual Congress of the German Neurosurgical Association, Harzburg, Germany.

The re-orientation of locomotion and posture in the spinal man. (Richard Kovacz Memorial Lecture.) Roy. Soc. Med. I, 47. 
I 4 Sport for the disabled as a world problem. Int. Seminar of British Council for Rehabilitation, July, I968, Brighton, in 'Rehabilitation'.

I 5 Talents and rehabilitation. Proc. 4th Pan-Pacific Congress on Rehabilitation, Hong Kong.

I 6 Organisation of spinal units. Proc. 4th Pan-Pacific Congress on Rehabilitation, Hong Kong.

I 7 Initial treatment of traumatic paraplegia and tetraplegia. Address given at the 36th Annual Meeting of the American Association of Neurological Surgeons, 7th April, Chicago.

I 8 Deformities of the spine following surgical procedures. Proc. Ann. Scientific Meeting of the Intern. Med. Soc. of Paraplegia, November 1968, in Israel, Paraplegia, 7, 38 .

I I9 The problem of pressure sores in spinal paraplegia and tetraplegia. Third Symp. on Rehabilitation of the disabled in Africa and the developing countries: Lusaka: Ioth-I4th Feb. I969.

I20 Spinal deformities in traumatic paraplegics and tetraplegics following surgical procedures. Paraplegia, 7, 38.

I2I Die initiale Behandlung von Querschnittslähmungen des Rückenmarks nach Frakturen der Wirbelsäule. Die Wirbelsaule in Forschung und Praxis, Band 42 p. 58-69 (Publisher: Hippokrates-Verlag, Stuttgart).

I 970

Spinal shock and reflex behaviour in man. Paraplegia, 8, No. 2.

Spinal injuries, initial treatment of fractures and dislocations in traumatic paraplegia and tetraplegia. Folia traumatologica Geigy.

El tratamiento do la paraplegjia traumatica. Rehabilitacion, 2-Fasc. 2 April.

Prostigmin Assessment test of fertility in spinal man. Paraplegia, 9, No. I.

Die Rehabilitation der Schwerstbehinderten, speziell der Querschnittsgelahmten. Deutsches Med. Fournal, March, I40-I 43.

Neuro-Traumatologie mit Einschluss der Grenzbebiete, Vol. II Verletzungen des Rückenmarks (Injuries of the Spinal Cord) Ed. Sir Ludwig Guttmann, including my own chapter on Spinal Cord Injuries (Publisher: Urban \& Schwarzenburg, Munich, Berlin, Vienna.

The neurogenic bladder: topical problems (Neurogene Blasenstörungen. Publisher: Georg Thieme Verlag, Stuttgart).

Experimental studies on the value of archery in paraplegia. Paraplegia, II, I59-165. Spinal Cord Injuries: Comprehensive Management and Research (Publisher: Blackwell Scientific Publications Ltd., Oxford, England) October 1973.

The value of sport for the severely physically handicapped. Hexagon Roche, 2, No. 3 . Zur Problematik der Wirbelsäulenfrakturen bei Querschnittsläsionen des Rückenmarks. Z. Orthop. II2, 9 I I-918.

Development of sport for the spinal paralysed. Hexagon Roche, 3, No. 7. Sport and the spinal cord sufferer. Nursing Mirror, November 6, 64, 65.

Second edition of Spinal Cord Injuries: Comprehensive Management and Research (Publisher: Blackwell Scientific Publications Ltd., Oxford, England). (73I pages.) Textbook of Sport for the Disabled (Publisher: H.M. \& M. Publishers, Limited, Milton Road, Aylesbury, Bucks, England). (I84 pages.)

37 Pressure sores (Handbook of Clinical Neurology Vol. 26. Injuries of the Spine and Spinal Cord, Part II. Eds. P. J. Vinken and G. W. Bruyn in collaboration with R. Braakman. Publisher: North-Holland Publ. Co. Ltd.) I976, pp. 463-476.

The conservative management of closed injuries of the vertebral column resulting in damage to the spinal cord and spinal roots. (Handbook of Clinical Neurology, Vol. 26. Injuries of the Spine and Spinal Cord, Part II. Eds. P. J. Vinken and G. W. Bruyn in collaboration with R. Braakman. Publisher: North-Holland Publ. Co. Ltd.) I976, pp. 285-306. 
I39 Sport in the rehabilitation of spinal paraplegics and tetraplegics. (Handbook of Clinical Neurology, Vol. 26. Injuries of the Spine and Spinal Cord, Part II. Eds. P. J. Vinken and G. W. Bruyn in collaboration with R. Braakman. Publisher: NorthHolland Publ. Co. Ltd.) i 976 , pp. 52 I-540.

I40 Spinal shock (Handbook of Clinical Neurology, Vol. 26. Injuries of the Spine and Spinal Cord, Part II. Eds. P. J. Vinken and G. W. Bruyn in collaboration with R. Braakman. Publisher: North-Holland Publ. Co. Ltd.) 1976, pp. 243-262.

I4I Tetraplegia in ankylosing spondylitis (Handbook of Clinical Neurology, Vol. 26. Injuries of the Spine and Spinal Cord, Part II, Eds. P. J. Vinken and G. W. Bruyn in collaboration with R. Braakman. Publisher: North-Holland Publ. Co. Ltd.) 1976, pp. I75-I83.

I42 Health deviation and rehabilitation in spinal paraplegia and tetraplegia. The Harben Lecture, 1976. The Royal Institute of Public Health \& Hygiene, Nov. 1976. Publ. in Community Health, 8, No. 4.

I43 Reflection on the 1976 Toronto Olympiad for the physically disabled. Paraplegia, I4, 225-240.

I44 Initial treatment of paraplegic patients. Symposium on Treatment of Paraplegic Patients, Tilburg, Holland, Nov. 1975. Publ. 1976.

I45 Total responsibility of the surgeon in the management of traumatic spinal paraplegics and tetraplegics. Paraplegia, 15, 285-292. 